OPEN ACCESS

International Journal of Management \& Entrepreneurship Research

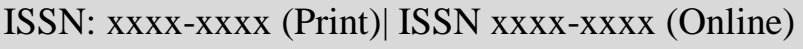

Vol. 1(1), pp. 42-58, March, 2019

Fair East Publishers

Journal Homepage: www.fepbl.com/ijmer

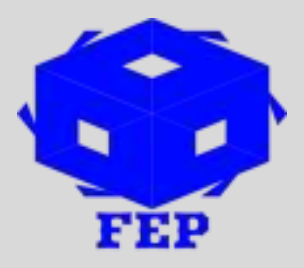

\title{
INTERNAL EQUITY AND CUSTOMER RELATIONSHIP MANAGEMENT IN SUBSISTENCE MARKETS: A COMPARATIVE AND A QUALITATIVE STUDY OF THREE PRIVATE COMPANIES IN BURKINA FASO
}

Dr. Théophile Bindeouè Nasse ${ }^{1,2}$, Yvonne Marie Sawadogo ${ }^{3}$

${ }^{1}$ University Institute of Initial and Continuing Education/ Ouaga 2 University (Burkina Faso).

${ }^{2-}$ University for Development Studies (Ghana).

${ }^{3}$ University of Laval (Canada)

*Corresponding Author: Dr. Théophile Bindeouè Nasse ${ }^{1}$

Corresponding Author Email: nassetheophile2009@gmail.com

Article Received: 25-03-19 Accepted: 31-03-19 Published: 05-04-19

Licensing Details: Author retains the right of this article. The article is distributed under the terms of the $\begin{array}{lllll}\text { Creative } & \text { Commons } & \text { Attribution-NonCommercial } & 4.0 & \text { Licence }\end{array}$ (http://www.creativecommons.org/licences/by-nc/4.0/) which permits non-commercial use, reproduction and distribution of the work without further permission provided the original work is attributed as specified on the Journal open access page.

\begin{abstract}
The concept of internal equity in the customer relationship management is often overlooked by Burkina companies, causing thereby a reduction in profitability. Equity and ethical marketing practices are essential to the survival of Burkina companies, especially in this context of the globalization of the economy, where fair trade values are advocated, and competition is tough. On the basis of this observation, to help identify the contribution that fair business-to-customer practices could bring not only to the economic development of enterprises, but also to the eradication of poverty in the subsistence markets, this article presents the results of an exploratory research concerning three companies in Burkina Faso (two small and medium-sized enterprises (SMEs) and a very small company (VSE)). The results show current practices as well as challenges and limitations observed within these companies. The data collection was carried out using an interview guide addressed to the customers of these three companies in Burkina Faso. The data is collected with an audio voice recorder and then transcribed by hand using SONY audio software. The total number of interviewees is 51 . The research has helped to make
\end{abstract}


our contribution to the development of literature on markets livelihood which is also poorly documented and to make some suggestions to explore and to develop internal equity practices. The results show that internal equity has an influence on customer satisfaction and thus on sales' growth.

Keywords: Equity, customer satisfaction, repurchases, sales, subsistence markets, marketing

\section{INTRODUCTION}

One particularity of the livelihood markets is the narrowness of the consumer market ; indeed, almost all the market served is local and this narrowness is revealed in quantitative and qualitative terms. In this context, the adoption of a marketing approach is appropriate to better meet the needs of the subsistence market and business growth needs. This is why domain Application of this research is that of marketing. The approach in this research makes it possible to structure the work around the following fundamental questions:

1. What is internal equity in customer relationship management?

2. What are the effects of the perception of internal fairness on customer satisfaction?

3. What are the effects of the perception of internal equity on repurchase?

4. What are the effects of the perception of internal equity on the turnover of small and medium-sized enterprises (SMEs) and very small enterprises (VSEs) from Burkina Faso?

The present research begins with a review of the literature, followed by the presentation Research model and research hypotheses are, then the methodology, results, the discussion of the results, are the contributions and limitations are and finally the general conclusion.

\section{LITERATURE REVIEW}

A more in-depth review of the literature reveals what has been addressed by many authors who have made their eminent ideas prevail.

Work on equity are rooted in social psychology, sociology and organizational theories; thus, the first studies on the subject go back to the sixties, with the research of pioneers such as Homans (1961), Blau (1964) and Adams (1965) having led to the identification of the dimensions of justice. Equity is one of the three dimensions of justice perceived and identified by theorists working in the field of social exchange. These dimensions are: distributive justice or equity (which takes into account the perception of the inputs and outputs of the exchange, i.e. the valuation of gains versus investment), procedural justice (which deals with the means implemented in the exchange process) and interactional justice (which deals with the interpersonal aspects in the exchange process) as stated by Prim and Pras (1999). In marketing, studies on this subject are rather rare (Oliver and De Sarbo, 1988). As announced in the introduction, the works will be limited to the first dimension concerning distributive justice.

\section{The Theory of Distributive Justice}

Homans (1961) Adams (1963) Zeithaml, Lemon and Rust (2004), Perreti (2004), Aravindakshan and al .(2004), Morrisson (2005), Olsen (2007), Nasse (2012) evoke the notion of equity resulting from the comparison that an individual establishes between what he perceives from an exchange " output, profit "and the contribution it brings to the exchange" input, 
investment, bet ". These authors showed that equity not only influences customer satisfaction but also, it influences the customer's purchase. Thus, equity in general and internal equity particularly in the business-customer exchanges is a very important.

Sabadie (2000), Kotler and Dubois (2003), Perreti (2004), Juët (2005), Van Laethem et al. (2007), Akouwerabou and Bako (2014) claim to be in favor of the notion of fair price in the sense of fair price as the balance between the needs of the consumer and the interests of the company, avoiding unfair practices or unlawful in price fixing. Also, a tripartite vision of distributive justice was devised by Deutsch (1975) to take into account certain realities of industrial societies where equity may also depend on other social functions such as equality and needs met.

\section{The Theory of Quality}

Kotler and Dubois (2003), Demeure (2008), Van Laethem and Body (2008), Nasse (2012), state that customer relationship management requires the company to produce good quality products and prices that meet the expectations of the customer. They abound in the sense of the theory of quality by showing that the consumer also takes into account not only a fundamental criterion which is the quality of the product, but also another fundamental criterion which the quality of the services is induced. Therefore, put see that the concept of quality is very important for customers. This concept of quality is often associated with that of the price. The customer judges the offer by making a quality / price ratio.

\section{The Theory of Satisfaction}

Ladhari (2005), Vanhamme (2004), Gandhi (2011), Bashar, Ahmad and Wasi (2012), Nasse (2012) talk about customer satisfaction and according to these authors, fairness and emotional reactions are antecedents to satisfaction. For these authors equity is an antecedent of satisfaction.

\section{The Theory of Repurchase}

Simon (2000), Van Laethem and Body (2008), Kitchathorn (2009), Nasse (2012) demonstrates that satisfaction has a significant influence on the repurchase intentions. For these authors, a satisfied customer does not intend to break with the company but to continue to buy the company's products and services. They establish a link between the concept of fairness and the intentions to repurchase.

\section{The Theory of Growth}

Morrisson and Matthew (2003), Ouédraogo (2007), Nasse (2012), Shamba and Livian (2014) succinctly mention the growth of turnover of the business by showing that companies need to showcase a number of managerial practices. According to these authors, looking for customer satisfaction is a very important thing. Customer satisfaction necessarily drives the growth of the company's turnover. 


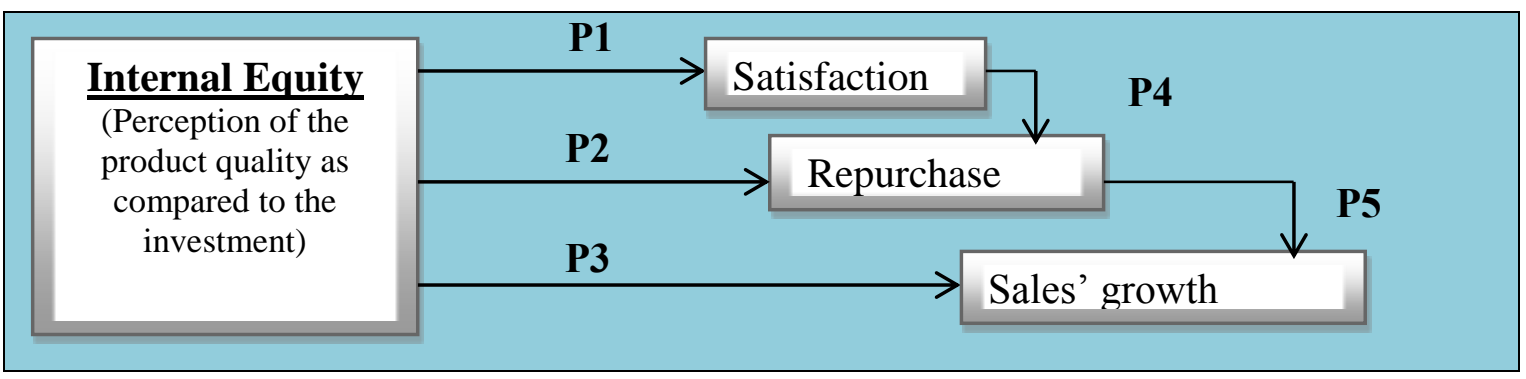

Research model and propositions [personal source]

- proposition 1 : Internal equity influences customer satisfaction.

- proposition 2 : Internal equity influences repurchase.

- proposition 3 : Internal equity influences sales growth.

- proposition 4 : Satisfaction influences repurchase.

- proposition 5 : Repurchase influences sales' growth.

\section{METHODOLOGY}

Research posture: This research is an exploratory one because there have not yet been researchers in the context Burkinabe who led such research on a theme like this. The epistemological posture is constructivist. According to Roche $(2003 ; 47)$ "The purpose of qualitative studies is therefore to understand the needs of the interviewees, but also - or even especially their motivations, their attitudes, their behavior, their retentions or their language ".

Research context: The research is carried out in the context of Burkina Faso, particularly in the capital city of Ouagadougou. The native language of respondents is French. Therefore, the interviews are conducted in French and then the verbatim is translated into English.

Sampling procedures: The interviewees were chosen on the basis of a convenience sample where the first customer is interviewed, the second until saturation is reached. In all, the sample is composed of 51 interviewees (23 interviews conducted in the field of vocational training, 14 in the printing service sector and 14 in the restaurant sector). The criterion of saturation is the sole criterion for stopping the collection of data because in general the last conducted interview does not bring more information. However, it is ensured that customers' level of education or culture allows them, in principle, to answer questions.

Duration of the interviews: The interviews were carried out at a given time chosen by the interviewees. The duration of the interviews is from twenty minutes to thirty minutes.

Unit of analysis: The unit of analysis is the experience customer that purchases the services or the products of one of the three companies that are subject to this research.

Research instruments: The research instrument is the semi-structured interview guide that are constructed with five specific themes. The interview guide is composed of five main topics. The interview guide is pretested with ten respondents. Then, the interview guide is subject to some modifications in order to make its contents easily understandable by the respondents. The semistructured interview guide is validated by at least two lecturers, and it is administered again to the respondents. 
Data collection procedure: The recordings of interviews are made using an audio voice recorder. Then the data is transcribed by hand using an audio software "SONY Sound Organizer" in order to facilitate the analysis. For this purpose, semi-structured interviews are conducted with customers who purchase the products of three private companies in the context of Burkina Faso. One company in the training sector, one company in the printing sector and one company in the catering sector

Data analysis: The data is transcribed by hand using an audio software. A content analysis is done to highlight the themes deemed relevant.

Validation of the research: The respondents are approached several times to make sure that their still have the same views. A post validation of the data is done and the respondents reaffirmed the same points of view.

\section{RESULTS}

The presentation of the data will be done in two stages. The first step will be to present the qualitative data that relate the expectations, the motivations, other value judgments consumers giving results that cannot be quantified. Such an approach is comprehensive insofar as qualitative data can confirm realities theoretically observed. The following table contains the details of the sample:

Table 1: Summary of the details of the study sample (personal source)

\begin{tabular}{|l|c|c|c|}
\hline Business & Men & Women & Total interviewed \\
\hline Training center & 9 & 14 & $\mathbf{2 3}$ \\
\hline ENT SARL & 12 & 2 & $\mathbf{1 4}$ \\
\hline Restaurant & 13 & 1 & $\mathbf{1 4}$ \\
\hline Total interviewed & $\mathbf{3 4}$ & $\mathbf{1 7}$ & $\mathbf{5 1}$ \\
\hline
\end{tabular}

The content analysis of the 36 semi-structured interviews revealed 4 themes as on the following table 2 .

Table 2: Different themes identified (personal Source)

\begin{tabular}{|l|c|c|}
\hline Themes & Frequencies & Percentages \\
\hline Satisfaction (joy) & 83 & $34.15 \%$ \\
\hline Dissatisfaction (disappointment, dissatisfaction) & 70 & $28.80 \%$ \\
\hline Equity & 49 & $20.16 \%$ \\
\hline Repurchase & 41 & $16.87 \%$ \\
\hline
\end{tabular}

(Source: Nasse, data analysis)

After cutting into different themes, an analysis of the so-called thematic categorical content which allowed to verify our propositions and to give answers to our questions of departure.

This study demonstrates that internal equity in business-to-customer interactions affects customer satisfaction and re-purchase intentions.

\section{- Internal equity influences customer satisfaction.}


When customers perceive that a company's offer is equivalent to their investments, then they may be satisfied with the transaction or purchase. In the first business professional training, we find that most customers are satisfied; witness the reaction of three customers who attended training courses:

" Uh! According to me, I think that training is good; compared to the investment I think it's acceptable ... I would say that I am satisfied with the moment when I have already given my appreciation of what we give as training I would say that it's okay. (Interview 1)

" I think the price matches the quality of the courses given here. The training is super cool. We appreciate the way they teach in order to educate us, to train us I think the price is fair to the training ... No, I'm satisfied I learn a lot. " (Interview 3)

" Well, I would say that I am quite satisfied because the cost is not very high like that but the teaching is good, that's the teaching it is quality. "(Interview 5)

In the second company, which is known as " ENT SARL And who offers photocopying services, the reaction of the customers is the same. As evidenced by the responses of five customers interviewed:

" Ok the quality, I can say that the quality is great! It's better! Myself, I was called by a friend as we are heads of institutions that means our year-end reports there we seek quality services so that the minister even appreciates the scriptures and I been called by a friend and we came and I am really satisfied, the report itself is already at the ministry and it is this service did that. " (Interview 24)

" Uh! I would say that the quality is good that's why I always come back every time and as you talk about investments I'm talking about the price offered here what. It's okay! It's affordable. (...) frankly, I do not know what to say but, value for money here is there. Yeah, the quality is there and the price is so affordable it's open to everyone so I find myself here. "(Interview 25)

" Hmm thank you, especially a lot of courage for the master because it's not an easy phase. Compared to your question I believe that the service rendered compared to the price, I find even a great satisfaction fifteen francs for quality copies, even the paper when you only take consumables at this price I do not think you can have quality products. " (Interview 26)

" Yes, I would say that not their price is satisfactory, well what's going, that since I'm here my photocopies I'm doing there, the price me especially it suits me and then their quality too, good I see when they make their photocopies I take I see everything in it is legible, it's clear, and then 
it's okay so that's what always leads me to go home and then it's next of me too it is correct. $"$ (Interview 27)

" I think the quality of the copies here is better compared to the investment we make. For example, they make me the copy at fifteen francs the page and it is very legible, so it's good. I am satisfied. (Interview 28)

\section{- Internal equity influences re-purchase.}

In addition, when customers perceive that the supply of a company is equivalent to their investments, then once satisfied they can make repurchases which is beneficial to the company. Relevant illustrations can be taken in the professional training business where we find that the reflex of satisfied customers is to continue their buying behavior and not to break with the company:

" (....) Yes, in terms of quality / price it is a very good report, it is fair and I am really satisfied and I intend to return next year." (Interview 11).

"(...) Vocational training side I agree that I like it, but one cannot agree on all plans. But I will register again." (Interview 23).

The reflex is the same for customers of ENT SARL, which offers photocopying services:

"Yes, I already said, I'm still one of the oldest customers of this house so if I always come because it's my account here and I think that really the quality of work is intimately related to the price we can have something really good in terms of quality of service at a reasonable cost. "(Interview 26).

"Yes, I would say that their price is not satisfactory, well what's going on, so that since I'm here my photocopies I'm doing there, the price especially suits me "(Interview 27).

" I'm happy with the service I get at ENT. I am more than satisfied every time I come here. In addition, the atmosphere is friendly and fraternal. That's all what will keep me coming to ENT. (Interview 28).

Answers from satisfied customers of the coffee served in the restaurant go in the same direction:

"Yes, I am satisfied in any case. Yeah, I am satisfied for example when I have a lot of work to do, I take it at any time anyway. And I think it's good. Yes, I will come every day that God does; if I am passing I will stop and drink coffee here. (Interview 47) 
"I am satisfied. And I will continue drinking coffee here because of the atmosphere and the price. (Interview 48).

\section{- Internal equity influences the growth of business turnover.}

As can be seen, a company that takes into account internal equity in the process of managing its customer relationship increases customer satisfaction and therefore its revenue growth because a satisfied customer can return to make purchases and even bring customers back to the business, which can increase the company's revenue. First, Interview 6 from a respondent from the Vocational Training Center illustrates:

" It's fine,yes it's very good! I am satisfied with the investment I made compared to the training received; I think it's fair. I think what I get as training here is the best. This is great and I will bring customers even to add." (Interview 6)

Interviews from the business SARL ENT demonstrate:

" (...) Me the ninth time I've been here no, no, I have nothing to blame them for. Yes, Yes, Yes. The proof is that I myself bring customers here, here I am, there are three people who brought me here but myself I brought four people it's how much three plus four it's been seven already...(...) So, sincerely, we will continue to come here and people who are looking for quality products, we have told them the corner. (Interview 24).

" (...) I am satisfied and I am currently there, so, I continue to pay. "(Interview 25).

" So, I am very happy with their work. Of course, the price itself is fair so that's why I keep going there, so that's good." (Interview 27).

Satisfied customers of the restaurant's cafe are also ready to continue buying coffee, something that can increase the company's turnover:

"In my opinion I am satisfied, I am satisfied. Yes, I will come back of course. We will continue to drink it."(Interview 46).

\section{- Satisfaction influences repurchase.}

Satisfaction following the perception of internal equity, brings the customers to make repurchases. It is noted that at the level of the three companies it is perceived.

First at the company ENT SARL satisfied customers make re-purchases testifies what customers say

" (...) I am still one of the oldest customers of this house so if I come always because I find my account here and I think that really the quality of work is intimately related to the price we can have something of really good in terms of quality of service at a reasonable cost. I do not know it's you who are economists but politics I praise it, I think it's really good what it was the first gentleman I saw make an impression at twenty-five francs at the university here was the first one I saw doing that; his business grew quickly here; (...) Where I do not find satisfaction I do not leave again; except when I do not really have the choice and that in terms of copying it never happened what, it never happened. (Interview 26). 
" Good to see me here and come back several times so the fact that I'm still there is already a sign that I am satisfied with the services I receive here. Good as long as there is satisfaction, I will continue to come. (Interview 34).

Satisfied customers at the training center renew their registrations:

" (....) Yes, in terms of quality / price it is a very good report, it is fair and I am really satisfied and I intend to return next year. (Interview 11).

Satisfied customers of the restaurant's cafe continue to buy coffee, something that can increase the company's sales:

"I am satisfied. And I will continue drinking coffee here because of the atmosphere and price. (Interview 48)

\section{- Repurchase influences the growth of companies' sales.}

When customers of a company are loyal to the company's products or services by re-purchasing the same products or services, this allows the company to increase its turnover. This is evidenced by the views of a few customers and especially the managers of the three companies: "(...) Me the ninth time I've been here no, no, I have nothing to blame them for Yes, yes, yes The proof is that I myself bring customers here, here I am; there are three people who brought me here but myself I brought four people it's how much three plus four it's already seven ... (....) and it makes grow its turnover. Sincerely, we will continue to come here and people who would look for quality products, we told them the corner. "(Interview 24).

"(...) I am still one of the oldest customers of this house so if I come always because I find my account here and I think that really the quality of work is intimately related to the price we can have something really good in terms of quality of service at a reasonable cost. I do not know it's you who are economists but politics I praise it, I think it's really good that it was the first man that I thought I would make an impression at twenty-five francs at the university here it was the first one I saw doing that, his business grew quickly here (...) Where I do not find satisfaction I do not leave again except when I do not really have the choice and that in terms of copying it never happened what, it never happened. (Interview 26). "(...) In any case, I do not complain, all my customers are satisfied and they come back to make photocopies and it's ok the turnover is growing, but uh I cannot tell you the amount" (Responsible of ENT SARL)

"(...) When the students are satisfied with their training and come back laughing again, this increases the turnover" (Interview responsible of the training center).

"(...) Yes the fact that the customers re-buy increases my turnover and at the beginning of the 
activity, I gained a lot, the turnover was big but now the sale has a little lower and the Turnover too, growth is not like before "(Responsible of the restaurant).

A comparative study of the verbatim of the prospects of the three (3) companies brings out the following

result:

-The verbatim of the interviewees of the training center is characterized on the one hand by expressions such as "acceptable", "happy", "superb", "fair", "satisfied", "satisfactory", " good "which allow to perceive, in the figurative sense, an accomplishment which can be understood literally as the satisfaction of a major part of the customers; and, on the other hand, expressions such as "deplores", "dissatisfied", "disappointed", "discouraged", "expectations", "expensive", "inferior" that suggest a certain appetite, a curiosity, and an ambition in the figurative sense, which can be translated literally as dissatisfaction. This desire, apparently unfulfilled by some customers, seems to contribute to creating a certain state of deep dissatisfaction, even of confusion.

- In ENT SARL, however, verbatim is entirely characterized by such expressions as: "super", "happy", "better", "fair", "satisfied", "correct", "Great" which allow to perceive, in the figurative sense, a total fulfillment which can be understood in the proper sense as the fulfillment. This state of accomplishment reflects the total satisfaction of the customers.

-The verbatim of the interviewees of the restaurant is characterized on the one hand by expressions such as: "good", "happy", "superb", "appreciable"," satisfied "," satisfactory ","good

" which let perceive, at the figurative meaning, an accomplishment that can be understood literally as fulfillment. This state of accomplishment reflects the satisfaction of some customers and the other terms "dissatisfied", "it does not work", "does not equate" which allow us to perceive a certain disappointment, in the figurative sense, showing a recurrent state of dissatisfaction with some of the customers.

For companies whose customers are satisfied, the chief executive's point of view is " growing revenue ". It is noted that companies that have a high rate of satisfaction are those whose turnover is growing (see table 3 below).

Table 3 : Comparison of satisfaction rate and turnover of companies

\begin{tabular}{|c|c|c|c|c|c|}
\hline Companies & $\begin{array}{l}\text { Number of } \\
\underline{\text { respondents }}\end{array}$ & $\begin{array}{l}\frac{\text { Number of }}{\text { dissatisfied }} \\
\text { respondents }\end{array}$ & $\begin{array}{l}\text { Number of } \\
\text { satisfied } \\
\text { respondents }\end{array}$ & $\begin{array}{l}\text { Satisfaction } \\
\underline{\text { rate }}\end{array}$ & $\begin{array}{l}\text { Statement of } \\
\text { revenue According } \\
\text { to the chief } \\
\text { executive of the } \\
\text { company }\end{array}$ \\
\hline $\begin{array}{l}\text { Training } \\
\text { Center }\end{array}$ & 23 & 4 & 19 & $82.60 \%$ & $\overline{\text { Growing }}$ \\
\hline ENT SARL & 14 & 0 & 14 & $100 \%$ & Growing \\
\hline Restaurant & 14 & 6 & 8 & $57,14 \%$ & Decreasing \\
\hline Total & 51 & 10 & 41 & & \\
\hline
\end{tabular}

(Source: Nasse, data analysis) 
For the company ENT SARL the most popular products are: photocopy first, printing second; followed the paper, the machine and the computer (see table 4 below).

Table 4: Frequency of citation of products ENT SARL

\begin{tabular}{|l|l|c|}
\hline Products & Frequency quote & Percentage frequency \\
\hline Photocopy & $65 / 92$ & $\mathbf{7 0 . 6 5 \%}$ \\
\hline Impression & $13 / 92$ & $\mathbf{1 4 . 1 3 \%}$ \\
\hline Paper & $09 / 92$ & $\mathbf{9 . 7 8 \%}$ \\
\hline Machine & $04 / 92$ & $\mathbf{4 . 3 4 \%}$ \\
\hline Computer & $\mathbf{0 1} / \mathbf{9 2}$ & $\mathbf{1 . 0 8 \%}$ \\
\hline
\end{tabular}

(Source: Nasse, data analysis)

For the training center the most popular products are: English first, computer science second, then come transport and logistics, civil engineering, secretarial, stock management, secretarial accounting (see table 5 below).

Table 5: Frequency of quotation of the products of the training center

\begin{tabular}{|l|l|c|}
\hline Products & Frequency quote & Percentage frequency \\
\hline English & $37 / 63$ & $\mathbf{5 8 . 7 3 \%}$ \\
\hline data processing & $09 / 63$ & $\mathbf{1 4 . 2 8 \%}$ \\
\hline Logistic transport & $05 / 63$ & $\mathbf{7 . 9 3 \%}$ \\
\hline Civil engineering & $05 / 63$ & $\mathbf{7 . 9 3 \%}$ \\
\hline Secretariat & $03 / 63$ & $\mathbf{4 . 7 6 \%}$ \\
\hline Stock management & $03 / 63$ & $\mathbf{4 . 7 6 \%}$ \\
\hline Accounting & $\mathbf{0 1} / 63$ & $\mathbf{1 . 5 8 \%}$ \\
\hline
\end{tabular}

(Source: Nasse, data analysis)

For the restaurant level the most popular products are: Nescafe and Espresso coffee (see table 6 below).

Table 6: Frequency of citation of restaurant products

\begin{tabular}{|l|l|l|}
\hline Products & \multicolumn{1}{|c|}{ Frequency quote } & Percentage frequency \\
\hline Nescafe & $21 / 27$ & $77.78 \%$ \\
\hline Expresso coffee & $6 / 27$ & $22.22 \%$ \\
\hline
\end{tabular}

(Source: Nasse, data analysis)

\section{DISCUSSION}

The results obtained in the field make it possible to compare theoretical research proposals with empirical results in order to check if they are confirmed and evaluate their degree of acceptance. After having presented and analyzed the results in the three data companies who operate in three different areas, it is observed that small and medium enterprises (SMEs) and very small enterprises (VSEs) Burkina must make efforts to satisfy their customers.

The results of the qualitative analysis provide a number of significant elements and confirm the initial proposals in the three companies studied. 
Firstly, the analysis of the content of the verbatim reports collected at the training center, ENT SARL and the restaurant shows that there is a link between internal equity and customer satisfaction:

- Internal equity influences customer satisfaction: Proposition 1 is confirmed.

Secondly, the analysis of the contents of the verbatim reports collected at the training center, ENT SARL and the restaurant show that there is a link between the internal equity and the intentions of repurchase:

- Internal equity influences the repurchase: Proposition 2 is confirmed.

Thirdly, the analysis of the content of the verbatim reports collected at the training center, ENT SARL and the restaurant shows that there is a link between the internal equity and the growth of the turnover of each company:

- Internal equity influences the growth of business sales: Proposition 3 is confirmed.

The results of this study show the relevance of the concept of internal equity in the relationship management customer. As of the three companies studied, internal equity is a factor of growth in sales, in line with the work of many authors who argue that companies, to be successful, must have fair practices

(Perreti, 2004; Hondeghem and Perry, 2009; Nasse, 2012). The perception of equity by the individual leads him to adopt beneficial behaviors for the company. On the contrary, the perception of " inequity " leads the customer to adopt behaviors that are not beneficial to the company (Perreti, 2004; Nasse, 2012). With the exception of ENT SARL, the other two companies, namely the training center and the restaurant, find it difficult to design an offer in which internal equity is truly perceptible to all customers. The main suggestion is that in sector 's activities in the training and of the restoration, there are more challenges to make available to customers a truly fair offer. Finally, the choice of the organizational structure of the firm in relation to its size may be another factor that explains the fact that a company innovates in terms of fair supply than the other (Ouédraogo, 2006). The company SARL ENT can better satisfy s are customers than the other two companies.

The verbatim show that the satisfaction due to the perception of internal equity, causes the customers to make repurchases. It is noted that at the level of the three companies it is perceived.

- Satisfaction influences repurchase: Proposition 4 is confirmed.

The verbatim of some customers and verbatim reports of the three companies show that some of the customers are loyal to its products or services of the enterprise by repurchasing the same products or services, this allows the company to increase its turnover:

- The repurchase influences the growth of revenues: Proposition 5 is confirmed.

\section{RESEARCH CONTRIBUTIONS}

First, the main contribution is the enrichment of the concept of internal equity. This concept has already been defined in Anglo-Saxon and French literature; Although there are other definitions of internal fairness, however, this study allows better reinforce this definition. There is therefore internal equity when the customer perceives that the price is proportional to the quality of the 
product he buys. In these conditions the customer perceives that the offer is fair (Peretti, 2004; Nasse, 2012). This means that in the customer relationship of a company the notion of internal equity is perceived when the product or service is adequate or fair. And the notion of internal equity in the management of the customer relationship should not be limited to the notion of "fair price"; it must include a fair administration, a fair governance of the exchange situation, and a fair remuneration, a fair valuation and consideration of the customer in the exchange relations between business and customer. Second, this research identified the creation of measurement tools to measure internal equity, customer satisfaction and the degree of repurchase. These tools were developed through the literature and their reliability and validity were tested using statistical tools. Thirdly, this research reveals, in the light of theories of fairness, that internal equity has an impact on customer satisfaction and repurchase intentions. This gives rise to operational implications that concede the opportunity for companies to seek more equitable exchanges with their customers based on their strategic desires. The various pieces of information in this research make it possible to make the link between the perception of internal equity, the satisfaction, the intentions of repurchases, and the growth of turnover of the companies. The behaviors and attitudes identified when customers perceive a fair and impartial exchange and that they are driven by their reason are: the willingness to invest again, the intention of not changing partners, and the intention not to break with the business (Perreti, 2004; Nasse, 2012). As this study has demonstrated different perceptions of equity across the industry by customers, companies seeking to achieve better results in terms of revenue growth may need to avoid unfair practices in order to rebalance and optimize the exchanges between company and customers by reducing the intentions of disruptions considerably. The state of the contributions that the present research brings out, makes it possible inevitably to bring a plus in the world of the research and the management in company by the proposal of the good practices of management not only the identification but also the consideration of specific factors of success in the context of trade at the level of small and medium enterprises (SMEs) and very small enterprises (VSEs) of Burkina Faso. Finally, new elements in relation to the state of knowledge have been brought in the light of the theory of equity and the data collected. The implementation on the ground has some challenges, which allowed us to refine the methodological approach (Metchebon Takougang, 2010). The above proposed model is then verified.

\section{Research Limits}

The concepts of internal equity and external equity are particularly difficult to define as the concept of equity is used in many disciplines and in different ways. It was necessary to find at best the concept of internal equity perceived by the customer in the field of marketing, a work that had been done only very rarely, especially in the African context and more precisely in Burkina. The development of an interview guide and a questionnaire in the sense of the study of internal equity was also the subject of a particular choice through the development of these tools in French language, which is more suitable to the research field. The concept of satisfaction has also required great attention when handling it. It was therefore necessary to focus on defining what is meant by customer satisfaction. The operationalization of the constructs carried out as 
part of this work was conducted jointly by the analysis of the literature and the results of an exploratory study. However, the realization of this exploratory study takes place in the particular context of the small and medium enterprises (SMEs) and very small enterprises (VSEs) of Burkina Faso. The choice of variables, the development of the interview guide and issues were linked to this context which can therefore lead to bias in the generalization of the results.

\section{CONCLUSION AND IMPLICATIONS}

The research reveals that internal equity influences customer satisfaction and re-purchase intentions. Inner equity has many effects on the growth of the turnover of small and mediumsized enterprises (SMEs) and very small enterprises (VSEs). These effects can be positive or negative on the turnover of the company. Internal equity has many effects on the satisfaction of a company's customers. In the light of equity theories, this research shows that domestic equity has effects on customers' re-purchases. The effects of perception of internal equity can be positive or negative for the company in terms of re-purchase (Perreti, 2004; Nasse, 2012). Internal equity has also an effect on the sales' growth of small and medium enterprises (SMEs) and very small enterprises (VSEs) in the context of Burkina Faso. The effects of the perception of internal equity can be positive or negative for the company (Perreti, 2004; Nasse, 2012) in terms of revenue growth. The inclusion of internal equity in the company-customer exchanges will increase the growth in sales of small and medium enterprises (SMEs) and very small enterprises (VSEs) of Burkina Faso. In the end, striving to ban unhealthy practices, companies increase the quality of their products and services. This helps to strengthen their competitiveness (Akouerabou and Bako, 2014).

\section{Implications for Small And Medium-Sized Enterprises (SMEs):}

In the light of equity theories, this research shows that internal equity affects customer satisfaction and repurchase intentions. The avoidance of unfair practices helps to rebalance exchange between customer business significantly reducing customer lost. The responsiveness of a company must be quick and efficient when it comes to repair a situation related to illegal practices to anticipate the disadvantages associated with these practices. For this, a company must strengthen its communication with its customers and know how to use its assets to diagnose and solve problems related to the management of its customers [ Friedrich, 2014]. It must control information issued by each customer to ensure that their customers are always satisfied exchanges and avoid illegal exchanges.

\section{Future Research}

The study has been performed in the specific sector of small and medium enterprises (SMEs) and very small enterprises (VSEs) in Burkina Faso. It would therefore be useful and important to extend this study in large companies to check whether the results will be the same as in small and medium-sized enterprises (SMEs) and very small enterprises (VSEs), to significantly enrich the knowledge in this field. 


\section{References.}

Adams, J. S., 1963, Towards an understanding of inequity. Journal of Abnormal and Social Psychology, 1 (67), 422-436.

Akouwerabou, D. B., and Bako, P.,2014, Corruption effects on private enterprises productivity in developing countries: Firm level evidence from Burkina Faso. British journal of economics, management and trade, 6(2), 129-144.

Aravindakshan, A., Rust, R. T., Lemon, K. N., and Zeithaml, V. A., 2004, Customer equity: making marketing strategy financially accountable. Journal of Systems Science and Systems Engineering, 13 (4),1-15.

Bashar, A., Ahmad, I. and Wasi, M. (2012) A study of influence of demographic factors on consumer impulse buying behaviour. International journal of management and strategy, 3(5), $1-18$.

Beau, M., 2003, L'art de la thèse. $2^{\text {ème }}$ éd. Rév., La Découverte, Paris, France.

Blau, P., 1964, Exchange and Power in Social Life. John Wiley and Sons, New York, USA.

Brewer, G. A., and Selden, S. C., 2000, "Why elephants gallop: assessing and predicting organizational performance in federal agencies." Journal of public administration research and theory, 10(4), 685-711.

Bressy, G., et Konkuyt, C., 2004, Économie d'entreprise. $6^{\mathrm{e}}$ éd. Dalloz, Paris, France.

Borg, C. et Blidner-Knittel, C. (2009) Sales channels connection to marketing communication and customer relationships. University of Gothenburg.

Demeure, C., 2008, Marketing. $6^{\text {ème }}$ éd. Dunod, Paris, France.

Deutsch, M. 1975, Equity, equality, and need: What determines which value will be used as the basis of distributive justice? Journal of Social Issues, 31, 137-149.

Friedrich, J. J., 2014, Comptabilité générale et gestion des entreprises. Hachette supérieur, Paris, France.

Ganassali, S., 2009, Les enquêtes par questionnaires avec sphinx. Pearson Education, Paris, France, 1-263.

Gandhi, S., 2011, Customer satisfaction, its antecedent and linkage between employee satisfaction and customer satisfaction: a study. Asian Journal of business and management sciences, 1(1), 129-137.

Homans, G. C., 1961, Social behavior: its elementary forms. Routlege and Kegan Paul, London, United Kingdom.

Hondeghem, A., et J. L., Perry, 2009, Numéro spécial du GEAP sur la motivation de service public et la performance. Revue Internationale des Sciences Administratives, 75(1), 5-10.

Juët, R., 2005, La boîte à outils du manager. $2^{\mathrm{e}}$ éd. Dunod, Paris, France.

Kitchathorn, P., 2009, Factor influencing customer repurchase intention: an investigation of switching barriers that influence the relationship between satisfaction and repurchase intention in the low-cost airlines industry in Thailand. University of South Australia.

Kotler, P., et B., Dubois, 2003, Marketing management. $11^{\grave{e}}$ éd. Pearson, Paris, France.

Ladhari, R., 2005, La satisfaction du consommateur: ses déterminants et ses conséquences. Revue de l'Université de Moncton, 36 (2), 171-201. 
Metchebon Takougang, S. A., 2010, Contributions à l'aide à la décision en matière de gestion spatialisée : étude de cas en management environnemental et développement de nouveaux outils. Thèse de Doctorat en Sciences de l'Ingénieur, Faculté Polytechnique, Université de Mons, Belgique.

Morrisson, O., 2005, Influence modératrice de l'équité externe sur la relation disconfirmation des attentes - satisfaction à l'égard des actions de service recovery. Université Lyon 3.

Morrisson, O., et Mathieu, J. P., 2003, Représentations du dysfonctionnement d'un service et les réponses de l'entreprise. 8èmes Journées de Recherche en Marketing de Bourgogne, Dijon, France.

Nasse, B. T., 2014, Internal equity as a factor of companies' economic profitability. Lambert Academic Publishing, Saarbrücken, Germany.

Nasse, B. T., 2012, The place of internal equity in customer relationship management. Lambert Academic Publishing, Saarbrücken, Germany.

Olsen, L. L., 2002, Modeling equity, satisfaction and loyalty in business to consumer markets. Norwegian School of Management.

Ouédraogo, A., 2007, Strategic management in African firms: a local perspective. Problems and Perspectives in Management, 5(1), 82-94.

Ouédraogo, A., 2006, Innovation, compétitivité et croissance des PME : expériences de deux entreprises du secteur biotechnologique au Québec. Les actes du $5^{e}$ congrès de l'académie de l'entreprenariat, Université de Sherbrooke.

Ouédraogo, A., 2003, Alliances stratégiques dans les pays en voie de développement, spécificité, management et conditions de performance: une étude d'entreprises camerounaises et burkinabés. Université de Montréal.

Perconte, B., 2003, 50 fiches pour comprendre le marketing. 2e éd. Paris, Bréal.

Perreti, J. M., 2004, Les clés de l'équité : enjeu managérial. Éditions d'Organisation.

Prim, I., and B., Pras, 1999, "Friendly" complaining behaviors: toward a relational approach. Journal of Market-Focused Management, 3(3-4), 333-352.

Reinartz, W. et al. (2004) The CRM process: its measurement and impacts on performance. Journal of Marketing Research.

Sabadie, W., 2000, Les apports des théories de la justice au marketing des services. $16^{\grave{e}}$ congrès $A F M$, Canada.

Shamba, P. B., et Y. F., Livian, 2014, Le management africain introuvable : pour une approche de l'hybridité segmentée. Communication pour la 4ème conférence Atlas-AFMI, Marseille, France.

Simon, P., 2000, Pour une clarification de la relation entre attitude envers la marque et fidélité à la marque vers la mise en évidence d'un modèle intégrateur. Università Ca' Foscari, Venezia. Urbain, C., 1979, De l'équité à la perception et à l'acceptation du prix par le consommateur : la notion de juste prix. Université de Nantes. 
Vanhamme, J., 2002, La satisfaction des consommateurs spécifique à une transaction : définition, antécédents, mesures et modes. Recherche et Applications en Marketing, 17(2), $55-80$.

Van Laethem, N., Y., Lebon, et B., Durand-Mégret, 2007, La boîte à outils du responsable marketing. Dunod, Paris, France.

Van Laethem, N., et L., Body, 2008, Le plan marketing. $2^{\mathrm{e}}$ éd. Dunod, Paris, France.

Vanhamme, J., 2004, La surprise et son influence sur la satisfaction des consommateurs : synthèse des recherches et implications managériales. Revue Française du Marketing, 197(1), 46-47.

Zeithaml, A. V., K. N., Lemon and R.T., Rust, 2004, Return on marketing: using customer equity to focus marketing strategy. Journal of Marketing, 68(1),109-127. 